\title{
Hodgkin's Disease in Patients with Previous Infectious Mononucleosis: 30 Years' Experience
}

\author{
NILS ROSDAHL， S. OLESEN LARSEN， J. CLEMMESEN
}

British Medical fournal, 1974, 2, 253-256

\section{Summary}

Seventeen out of 17,073 people in Denmark who had had a positive reaction to a Paul-Bunnell test between the years 1940 and 1969 developed Hodgkin's disease after an interval of at least 12 months. This number was significantly $(P<$ 0.0002 ) greater than the expected number of two women and four men. Sixteen of those developing Hodgkin's disease were men. Case records, which were available for 12 of them, confirmed that they had had infectious mononucleosis. The number of cases of leukaemia that developed in the sample population was no greater than expected.

\section{Introduction}

There is a possible association between infectious mononucleosis and maglignant diseases. Cell lines derived from people with infectious mononucleosis resemble in many ways those isolated from leukaemia patients (Benyesh-Melnick et al., 1968). On morphological grounds Dameshek (1969) has suggested that infectious mononucleosis is a reversible, selflimiting form of lymphocytic leukaemia. The findings that the Epstein-Barr virus might be the causative agent of infectious mononucleosis (Henle et al., 1968) and that this virus is closely related to Burkitt's lymphoma also suggest a possible virological link between malignancy and infectious mononucleosis. Raised titres of Epstein-Barr virus antibodies may be found in patients with Hodgkin's disease (Levine et al., 1971), though Goldman and Aisenberg (1970) did not find them. Isolated cases of leukaemia and Hodgkin's disease after infectious mononucleosis have been reported (English, 1970; Levine et al., 1972), and four out of a series of 516 cases of Hodgkin's disease developed subsequent to infectious mononucleosis (Smithers, 1967). Kaplan (1972) saw 37 cases of Hodgkin's disease with a fairly definite history of infectious mononucleosis. The possible association between EpsteinBarr virus and lymphoproliferative states in man has recently been reviewed by Miller (1971).

The aim of the present investigation was to discover whether the risk of developing Hodgkin's disease is increased in people who have had a positive Paul-Bunnell reaction. This investigation was possible because in Denmark the records of serological diagnosis of infectious mononucleosis for most of the period from 1938 to 1970 have been centralized, and since 1943 malignant diseases have been reported to a national cancer registry.

Department of Medical Microbiology, University of Copenhagen NILS ROSDAHL, CAND. MED., D.P.H., Research Fellow (Present appointment: Assistant Medical Officer, National Board of Health, St. Kongensgade, DK-1264, Copenhagen)

Statens Seruminstitut, Copenhagen

S. OLESEN LARSEN, CAND. POLIT., Head of Department of Bio-statistics Finseninstitutet, Copenhagen,

J. CLEMMESEN, DR.MED., Director of Danish Cancer Registry
Patients and Methods

At the Statens Seruminstitut, Copenhagen, the Paul-Bunnell test is done by the method of Kristensen (1938), which includes agglutination after absorptions with ox erythrocytes and guinea-pig kidney. This method has been used continuously since 1939. From the records we collected personal data, including name, sex, birth date, date of performance of test, and titres, for each patient for whom the Paul-Bunnell reaction was positive at a titre of $1 / 32$ or higher. This criterion was met in 17,073 cases out of some 99,000 tests carried out. Funther information about patients when needed was obtained from their hospital records.

Of the 17,073 cases with the required level of titre 906 were excluded because of inadequate identifying information. In all cases only the first positive sample was used. Data from all persons whose birth date was known were transferred to punched cards. Details of their age and sex distribution have been published elsewhere (Rosedahl et al., 1973). Information on social class was not recorded.

Since 1943 the Danish Cancer Registry under the National Anti-Cancer League has received information on cases of malignant diseases in Denmark. Though notification is voluntary it is supplemented by scrutiny of all death certificates, and it can be considered practically complete (Clemmesen, 1965, 1969). Data about patients suffering from leukaemia and malignant lymphoproliferative diseases were collected from the records of the Cancer Registry for the period from 1 January 1943 to 30 June 1970. These data and those from the Paul-Bunnell register were processed at the North European University Computer Centre, Lundtofte, Denmark. All patients in the two registers with identical birth dates, regardless of sex and name, were put on two corresponding lists, which were checked by us personally. Most could then be discarded as they were obviously not identical, while others with the same binth dates were subject to funther investigation. All whose identity was not established with certainty were excluded from the study, as were also those in whom the finding of a positive Paul-Bunnell reaction was concurrent with the establishment of the diagnosis of Hodgkin's disease.

The case notes of the 17 remaining patients were requested from the general practitioners or hospitals who had treated them. The history of infectious mononucleosis was accepted as verified only if the diagnosis had been made at the time of illness and was supported by serological findings and the presence of fever, tonsillitis, and enlargement of peripheral lymph nodes. The initial titre had to be at least $1 / 64$, and after absorption with guinea-pig kidney it had to be equal to or less than two dilutions lower than the primary titre. The titre after absorption with ox erythrocytes had to be $1 / 16$ or less and decreased at least by three dilutions.

These criteria were seen from the case notes to be fulfilled in 12 of the 17 patients (cases 1-12). The case notes of the remaining five patients were unobtainable but in none was there any reason to doubt the diagnosis of infectious mononucleosis.

The expected number of cases of Hodgkin's disease among people listed in the Paul-Bunnell register was calculated by using the national sex- and age-specific incidence rates in five-year periods from 1943 to 1962 and taking into account the number of years at risk at different ages for each per- 
son. These rates are calculated in five-year periods by the Danish Cancer Registry (Clemmesen, 1965, 1967; table I). For the period 1963-70 the incidence rates for 1958-62 were used. Calender-specific incidences showed a limited increase in the incidence of Hodgkin's disease in the 20-29 age group from the time of establishment of the Cancer Registry to 1962. Unpublished results have shown a decreased incidence for males between 15 and 45 years of age and hardly any changes for females from 1958-62 to 1963-9.

\section{Results}

A total of 17 people were found from the records to have developed Hodgkin's disease after a previous positive PaulBunnell reaction. The number of cases of Hodgkin's disease to be expected from a sample of the Danish population of similar sex and age distribution as the population under study is shown in table II. Sixteen out of the 17 patients with Hodgkin's disease after a positive Paul-Bunnell reaction were men, which, by using a two-sided test, was different $(P=$ 0.02 ) from the sex ratio expected. The total number of patients with Hodgkin's disease found also significantly exceeded the expected number $(P<0.002)$, and the expected number of men (four) in relation to the observed number (16) was highly significant $(P<0.00001)$.

Information on the 12 patients with positive Paul-Bunnell reactions who also satisfied the diagnostic criteria of verified infectious mononucleosis is shown in table III. The sex ratio of these 12 patients was also significantly different $(P=$ 0.002 ) from the one expected, and likewise their number was different $(P=0.020)$ from that expected. Their age when the Paul-Bunnell reaction was positive and when Hodgkin's disease was diagnosed was generally higher in this

TABLE I-Average Yearly Number of Cases of Hodgkin's Disease per 100,000 Population. Results calculated in Five-year Periods from $1943-60$ according to Sex and Age

\begin{tabular}{|c|c|c|c|c|c|c|c|c|}
\hline \multirow{2}{*}{$\begin{array}{c}\text { Age } \\
\text { (Years) }\end{array}$} & \multicolumn{4}{|c|}{ Males } & \multicolumn{4}{|c|}{ Females } \\
\hline & $1943-7$ & $48-52$ & $53-7$ & $58-62$ & $1943-7$ & $48-52$ & $53-7$ & $58-62$ \\
\hline $\begin{array}{c}\leqslant 4 \\
5--9 \\
10-14 \\
15-19 \\
20-24 \\
25-29 \\
30-34 \\
35-39 \\
40-44 \\
45-49 \\
50-54 \\
55-59 \\
60-64 \\
65-69 \\
70-74 \\
75-79 \\
\geqslant 80\end{array}$ & $\begin{array}{l}0.2 \\
0.4 \\
0.4 \\
1.7 \\
2.3 \\
3.3 \\
3.6 \\
3.5 \\
2.7 \\
2.4 \\
1.7 \\
4.0 \\
3.7 \\
3.3 \\
2.6 \\
4.3 \\
1.0\end{array}$ & $\begin{array}{l}0.2 \\
0.4 \\
0.4 \\
2.1 \\
4.4 \\
4.5 \\
3.1 \\
3.1 \\
3.3 \\
2.2 \\
3.2 \\
3.1 \\
4.1 \\
5.0 \\
4.8 \\
1.8 \\
0.9\end{array}$ & $\begin{array}{l}0.0 \\
0.5 \\
0.6 \\
2.5 \\
4.9 \\
3.5 \\
3.1 \\
2.5 \\
3.5 \\
2.3 \\
5.4 \\
3.5 \\
4.2 \\
2.1 \\
8.1 \\
5.6 \\
2.1\end{array}$ & $\begin{array}{l}0.1 \\
0.3 \\
0.7 \\
2.8 \\
4.3 \\
6.2 \\
4.2 \\
4.1 \\
3.6 \\
3.8 \\
3.8 \\
3.1 \\
5.9 \\
6.4 \\
8.5 \\
7.0 \\
4.8\end{array}$ & $\begin{array}{l}0.1 \\
0.0 \\
0.4 \\
1.3 \\
2.2 \\
3.8 \\
3.2 \\
1.9 \\
1.7 \\
2.0 \\
0.7 \\
2.0 \\
2.1 \\
2.8 \\
1.6 \\
1.8 \\
1.6\end{array}$ & $\begin{array}{l}0.0 \\
0.3 \\
0.3 \\
1.7 \\
2.3 \\
3.5 \\
2.7 \\
1.9 \\
2.2 \\
2.0 \\
2.2 \\
3.1 \\
2.5 \\
2.0 \\
3.1 \\
1.6 \\
4.1\end{array}$ & $\begin{array}{l}0.0 \\
0.0 \\
0.3 \\
1.2 \\
3.8 \\
5.0 \\
2.0 \\
1.0 \\
1.4 \\
1.8 \\
1.7 \\
3.4 \\
2.9 \\
3.0 \\
1.8 \\
3.2 \\
4.1\end{array}$ & $\begin{array}{l}0.0 \\
0.2 \\
0.2 \\
1.8 \\
2.4 \\
3.0 \\
2.8 \\
1.9 \\
2.7 \\
2.9 \\
2.0 \\
1.8 \\
2.4 \\
5.2 \\
6.2 \\
3.6 \\
2.0\end{array}$ \\
\hline
\end{tabular}

TABLE II-Actual Numbers of Patients with Previous Positive Paul-Bunnell Reaction who developed Hodgkin's Disease over Whole Period and over Various Intervals after Reaction compared with Numbers expected. Numbers in Parentheses are those of verified Cases of Infectious Mononucleosis

\begin{tabular}{|c|c|c|c|c|c|c|c|c|}
\hline \multirow{2}{*}{\multicolumn{3}{|c|}{$\begin{array}{c}\text { Interval between Positive } \\
\text { Paul-Bummell Reaction and } \\
\text { Diagnosis of Hodgkin's Disease } \\
\text { (Years) }\end{array}$}} & \multicolumn{2}{|c|}{ No. of Males } & \multicolumn{2}{|c|}{ No. of Females } & \multicolumn{2}{|c|}{ Total } \\
\hline & & & Actual & Expected & Actual & Expected & Actual & Expected \\
\hline $\begin{array}{l}\leqslant 1 \\
-2 \\
-3 \\
-4 \\
-6 \\
\leqslant 6\end{array}$ & $\begin{array}{l}\cdots \\
\cdots \\
\cdots \\
\cdots \\
\end{array}$ & $\begin{array}{l}. \\
\because \\
\because \\
. \\
\end{array}$ & $\begin{array}{c}\text { * } \\
5(4) \\
6(5) \\
1(0) \\
3(3) \\
1 \text { (0) }\end{array}$ & $\begin{array}{l}0.27 \\
0.29 \\
0.29 \\
0.29 \\
0.54 \\
2.34\end{array}$ & $\begin{array}{l} \\
0 \\
0 \\
0 \\
1(0) \\
0\end{array}$ & $\begin{array}{l}0.12 \\
0.12 \\
0.13 \\
0.13 \\
0.26 \\
1.23\end{array}$ & $\begin{array}{l}* \\
5(4) \\
6(5) \\
1(0) \\
3(3) \\
1(0)\end{array}$ & $\begin{array}{l}0.39 \\
0.41 \\
0.42 \\
0.42 \\
0.80 \\
3.57\end{array}$ \\
\hline & Total & .. & $16(12)$ & 4.02 & $1(0)$ & 1.99 & $17(12)$ & 6.01 \\
\hline
\end{tabular}

*Those observed were regarded as concurrent and were excluded (see text).

TABLE II-Data on Patients with Positive Paul-Bunnell Reaction who developed Hodgkin's Disease. Diagnosis of Infectious Mononucleosis was verified in 12 Patients (Cases 1-12)

\begin{tabular}{|c|c|c|c|c|c|c|c|c|c|}
\hline \multirow[b]{2}{*}{$\begin{array}{l}\text { Case } \\
\text { No. }\end{array}$} & \multicolumn{8}{|c|}{ Data at Time of Positive Paul-Bunnell Reaction } & \multirow{2}{*}{$\begin{array}{c}\text { Age at } \\
\text { Time of } \\
\text { Diagnosis of } \\
\text { Hodgkin's } \\
\text { Disease }\end{array}$} \\
\hline & \multicolumn{2}{|c|}{ Date } & Sex & $\begin{array}{c}\text { Age } \\
\text { (Years) }\end{array}$ & Occupation & Marital Status & $\begin{array}{l}\text { Presence of } 50 \% \text { of Mononuclear } \\
\text { Leucocytes by Differential Count in } \\
\text { Peripheral Blood }\end{array}$ & $\begin{array}{c}\text { Paul-Bunnell } \\
\text { Reaction } \dagger\end{array}$ & \\
\hline $\begin{array}{l}1 \\
2 \\
3 \\
4 \\
5 \\
6 \\
7 \\
7 \\
8\end{array}$ & $\begin{array}{l}\text { April } \\
\text { Nov. } \\
\text { Aug. } \\
\text { July } \\
\text { Sept. } \\
\text { June } \\
\text { Sept. } \\
\text { May }\end{array}$ & $\begin{array}{l}1952 \\
1947 \\
1953 \\
1950 \\
1962 \\
1957 \\
1966 \\
1964\end{array}$ & $\begin{array}{l}\text { M. } \\
M . \\
M . \\
M . \\
M . \\
M . \\
M . \\
M .\end{array}$ & $\begin{array}{l}37 \\
26 \\
24 \\
20 \\
29 \\
20 \\
27 \\
20\end{array}$ & $\begin{array}{l}\text { Farm labourer } \\
\text { Unskilled worker } \\
\text { Pharmacist } \\
\text { Skilled worker* } \\
\text { Accountant } \\
\text { Unskilled worker } \\
\text { Fireman } \\
\text { Skilled clerical } \\
\text { worker* }\end{array}$ & $\begin{array}{l}\text { Married } \\
\text { Unmarried } \\
\text { Unmarried } \\
\text { N.K. } \\
\text { Married } \\
\text { Unmarried } \\
\text { Married } \\
\text { Married }\end{array}$ & $\begin{array}{c}+ \\
+ \\
+ \\
\text { N.P. } \\
+ \\
+ \\
+ \\
+\end{array}$ & $\begin{array}{c}128 / 64 / 0 \\
128 / 32 / 0 \\
512 / 256 / 0 \\
256 / 256 / 0 \\
64 / 64 / 0 \\
64 / 16 / 0 \\
1,024 / 256 / 0 \\
64 / 16 / 0\end{array}$ & $\begin{array}{l}40 \\
27 \\
29 \\
25 \\
31 \\
23 \\
29 \\
22\end{array}$ \\
\hline $\begin{array}{r}9 \\
10 \\
11 \\
12 \\
13 \\
14 \\
15 \\
16 \\
17\end{array}$ & $\begin{array}{l}\text { March } \\
\text { March } \\
\text { May } \\
\text { July } \\
\text { Aug. } \\
\text { March } \\
\text { May } \\
\text { May } \\
\text { May }\end{array}$ & $\begin{array}{l}1964 \\
1969 \\
1959 \\
1953 \\
1954 \\
1952 \\
1949 \\
1960 \\
1957\end{array}$ & $\begin{array}{l}\text { M. } \\
\text { M. } \\
\text { M. } \\
\text { M. } \\
\text { M. } \\
\text { M. } \\
\text { F. } \\
\text { M. } \\
\text { M. }\end{array}$ & $\begin{array}{l}18 \\
23 \\
25 \\
22 \\
31 \\
23 \\
19 \\
23 \\
16\end{array}$ & $\begin{array}{l}\text { Clerical apprentice } \\
\text { Skilled worker } \\
\text { Unskilled worker } \\
\text { Farm labourer* } \\
\text { N.K. } \\
\text { N.K. } \\
\text { N.K. } \\
\text { N.K. } \\
\text { N.K. }\end{array}$ & $\begin{array}{l}\text { Unmarried } \\
\text { Unmarried } \\
\text { Unmaried } \\
\text { Unmarried } \\
\text { N.K. } \\
\text { N.K. } \\
\text { N.K. } \\
\text { N.K. } \\
\text { N.K. }\end{array}$ & $\begin{array}{l}+ \\
+ \\
+ \\
+ \\
+ \\
\text { N.K. } \\
\text { N.K. } \\
\text { N.K. } \\
\text { N.K. } \\
\text { N.K. }\end{array}$ & $\begin{array}{c}128 / 64 / 0 \\
512 / 256 / 0 \\
256 / 256 / 0 \\
1,024 / 256 / 0 \\
128 / 128 / 0 \\
256 / 256 / 0 \\
128 / 64 / 0 \\
256 / 128 / 0 \\
512 / 256 / 0\end{array}$ & $\begin{array}{l}23 \\
24 \\
28 \\
23 \\
34 \\
30 \\
25 \\
25 \\
18\end{array}$ \\
\hline
\end{tabular}

N.P. $=$ Not performed

N.K. = Not known.

- Serving compulsory military service at time of infectious mononucleosis.

†Titres stated: unabsorbed/after guinea-pig kidney absorption/after ox erythrocvte absorption. 
group of patients than in the total number of cases found in the Paul-Bunnell register. There was nothing remarkable in their geographical distribution.

By using similar methods to this described above two to three cases of lymphatic leukaemia and a similar number of cases of myeloid leukaemia were expected. No excess of patients with leukaemia has been notified to the Cancer Registry, however.

\section{Discussion}

We found that the risk of contracting Hodgkin's disease was significantly increased in males who between the years 1940 and 1969 had had a positive reaction to the Paul-Bunnell test. There was no similar finding in females. A change in name by marriage is unlikely to explain the sex difference since the patient's name at birth was recorded in the Cancer Registry.

Compared to the general Danish population the patients in this series suffered from infectious mononucleosis at a rather late age. This might indicate that the risk of developing Hodgkin's disease is increased only in those who contract infectious mononucleosis at an older age than average. In that event women with Hodgkin's disease would be expected to be fewer in our series, as their mean age was somewhat lower than that of the whole. But if there were no association between age at the time of a positive Paul-Bunnell reaction and subsequent incidence of Hodgkin's disease we calculate from age-specific incidence rates of Hodgkin's disease and the short period of observation that $70 \%$ of males and $47 \%$ of females in our series should have been over 20 when suffering from infeotious mononucleosis. Our findings were not very different (table III).

In no case was the diagnosis of Hodgkin's disease in doubt. The age distribution of our patients was different to that overall in Denmark, as our cases were among the relatively young persons with positive Paul-Bunnell reactions. Furthermore, few were observed over a long period because the annual number of positive Paul-Bunnell reactions in the early 1940's was some 300 and the number rose slowly throughout the period of the study (Rosdahl et al., 1973).

Hodgkin's disease can cause false-positive Paul-Bunnell reactions (Massey et al., 1953; Kenis et al., 1958). We found two patients with positive Paul-Bunnell reactions when first seen with Hodgkin's disease. They were not included in our study. In another patient there was an interval of three months between a positive Paul-Bunnell reaction and a conclusive diagnosis of Hodgkin's disease. This patient suffered from progressive symptoms during this period and was consequently not included in the study. Most of our cases of Hodgkin's disease were diagnosed from one to four years after the positive Paul-Bunnell reaction. Three of them (cases 2, 10, and 12) were diagnosed within one and a half years after an attack of infectious mononucleosis, but there was nothing to distinguish these patients from the others. Any error in our method of selecting cases is unlikely. Inaccuracy in the data would have resulted in fewer people with both diseases, and our findings for leukaemia seem to support the claim that the cases presented in table III were not there because of technical errors.

Whether our findings may have a general bearing on the relation between infectious mononucleosis and Hodgkin's disease is still to be proved. It might be claimed that both diseases were more prevalent in the same sections of the population. In Denmark, however, there is no known preponderance of Hodgkin's disease in any social or geographical subgroup (Clemmesen, 1964). Tissue types HL-Al and HL-A8 are common in patients with Hodgkin's disease in Denmark (Kissmeyer-Nielsen et al., 1973) as elsewhere (Falk and Osoba, 1971), but reponts on the distribution of HL-A types in patients with infectious mononucleosis are conflicting. Susceptibility to infections may be increased in the presymptomatic stages of malignant diseases, but Kaplan (1972) reported no evidence of increased susceptibility in the very early stages of Hodgkin's disease and we found no increase in cases of leukaemia.

There have been few epidemiological studies of the possible association between infectious mononucleosis and Hodgkin's disease. Miller and Beebe (1973) followed up 2,437 United States veterans with infectious mononucleosis diagnosed during service in the second world war and compared them with a control group. Though they found a higher mortality from lymphoreticular neoplasms the diagnosis of infectious mononucleosis was in doubt in some cases. They therefore concluded that useful results were unlikely to be obtained from large scale follow-up studies of patients with clinical infectious mononucleosis, as suggested by Dameshek (1969). A larger study was carried out by Connelly (Connelly and Christine, 1971; Connelly, 1973), who investigated deaths from all malignant diseases in 4,529 cases of infectious mononucleosis reponted to Connecticut State Department of Health since 1948. The overall number of deaths was not increased. There were four deaths from Hodgkin's disease, one from lymphoma, one from lymphosarcoma, and one from reticulum cell sarcoma. The total of seven deaths was significantly higher $(P<0.05)$ than expected. The interval between infectious mononucleosis and Hodgkin's disease ranged from three to 10 years and three of the patients were women.

Our findings and those of Connelly support the suggestion that infectious mononucleosis and Hodgkin's disease may be associated. Whether this association is limited to some common factor or has any aetiological significance has still to be discovered. Nevertheless, the explanation of our findings is unlikely to be that the initial illness in our patients represented early clinical manifestations of Hodgkin's disease presenting in an infectious mononucleosis-like form. The intervals between the two episodes in all of Connelly's cases and in most of ours were too long for that. Further investigations should primarily be directed towards identifying factors common to both diseases. If such factors seem likely a prospective study of selected cases of infectious mononucleosis might prove valuable. Basic biological research into the mode of action of Epstein-Barr virus may also yield significant results.

This study was supported in part by a grant from the Danish Medical Research Council. We thank Dr. Ebbe Kjems, head of the Streptococcal Department, Statens Seruminstitut, who put at our disposal the register of Paul-Bunnell reactions now being compiled in his department. We thank also all colleagues who submitted additional information on patients included in this study.

\section{References}

Benyesh-Melnick, M., Fernbach, D. J., Dessey, S., and Lewis, R. T. (1968). Fournal of the National Cancer Institute, 40, 111

Clemmensen, J. (1965 a). Statistical Studies in the Aetiology of Malignant Neoplasms I. Copenhagen, Munksgaard.

Clemmesen, J. (1964) Statistical Studies in the Aetiology of Malignant Neoplasms II. Copenhagen, Munksgaard.

Clemmesen, J. (1969). Statistical Studies in the Aetiology of Malignant Neoplasms III. Copenhagen, Munksgaard.

Connelly, R. R., and Christine, B. W. (1971). In Proceedings, 10th International Cancer Congress, ed. R. L. Clark et al. Chicago, Hear Book Medical Publishing.

Connelly, R. R. (1973). Personal communication.

Dameshek, W. (1969). In Infectious Mononucleosis, ed. R. L. Carter and H. G. Penman. Oxford, Blackwell.

English, J. M. (1970). Lancet, 1, 948.

Falk, J., and Osoba, D. (1971). Lancet, 2, 1118

Goldman, J. M., and Aisenberg, A. C. (1970). Cancer, 26, 327.

Henle, G., Henle, W., and Diehl, V. (1968). Proceedings of the National Academy of Science of the United States of America, 59, 94.

Kaplan, H. S. (1972). Hodgkin's Disease, Cambridge, Mass., Harvard University Press. 
Kenis, Y., Dustin, P., jun., and Peltzer, T. (1958). Acta Haematologica, 20, 329 Kissmeyer-Nielsen, F., et al. (1973). Histocompatibility Testing 1972, ed. J. Dausset and J. Colombani. Copenhagen, Munksgaard.

Kristensen, M. (1938). Acta Scandinavica Pathologica et Microbiologica, suppl. $37,399$.

Levine P. H., et al. (1971). Cancer, 27, 416.

Levine, P. H., Stevens, D. A., Coccia, P. F., Dabish, L., and Roland, A. (1972). Cancer, 30, 875.
Massey, F. C., Lane, L. L., and Imbriglia, J. E. (1953). Fournal of the American Medical Association, 151, 994.

Miller, G. (1971). Yale Fournal of Biology and Medicine, 43, 358.

Miller, R. W., and Beebe, G. W. (1973). Fournal of the National Cancer Institute, $50,315$.

Rosdahl, N., Olesen Larsen, S., and Thamdrup, A. B. (1973). Scandinavian Fournal of Infectious Diseases, 5, 163.

Smithers, D. W. (1967). British Medical fournal, 2, 337.

\title{
Prevalence of Hepatitis B Antigen and Antibody in Prostitutes
}

\author{
G. PAPAEVANGELOU, \\ D. TRICHOPOULOS, \\ T. KREMASTINOU, \\ G. PAPOUTSAKIS
}

British Medical fournal, 1974, 2, 256-258

\section{Summary}

We investigated the prevalence of hepatitis $B$ antigen (HBAg) and antibody (HBAb) in 293 prostitutes and in 379 pregnant women of similar age and of low socioeconomic level, who served as controls. HBAg was found in $4.4 \%$ of prostitutes and $3.4 \%$ of controls. The prevalence of $\mathrm{HBAb}$ was significantly higher $(P<0.001)$ in prostitutes $(56 \cdot 7 \%)$ than in controls $(24 \cdot 5 \%)$. The prevalence of HBAb was clearly age-dependent in both groups. Evidence of hepatitis $B$ virus infection significantly increased with the number of years in prostitution. The evidence of increased infection rates among prostitutes and their distribution support the hypothesis that hepatitis B infection is sexually transmitted.

\section{Introduction}

Recent studies suggest that hepatitis B may be transmitted by non-parenteral or at least inapparent routes (Cossart, 1971) and that sexual transmission may play an important role in the spread of the disease (Jeffries et al., 1973). Thus a high rate of infection might be expected among prostitutes. We therefore decided to test this hypothesis by studying the prevalence of hepatitis B antigen (HBAg) and antibody (HBAb) in prostitutes in Athens, where the incidence of hepatitis B virus infection is high (Papaevangelou et al., 1971). We report the results of the study in this paper.

\section{Subjects and Methods}

The study sample consisted of 293 registered prostitutes in the Greater Athens area. Their age, length of time in prostitution, and history of syphilis were ascertained by direct questioning and from the special records of regular medical examinations. An unselected sample of 379 pregnant women who were delivered in hospital served as controls. Nearly all of them were in social class IV or V (General Register Office, 1951). The age range of the prostitutes was 20-51 years (mean $30 \cdot 1$ ), which

\footnotetext{
Department of Hygiene and Epidemiology, School of Medicine, University of Athens, Athens 609, Greece

G. PAPAEVANGElOU, M.D., Associate Professor of Hygiene and Epi-

D. TRICHOPOULOS, M.D., Professor and Chairman, Department of Hygiene and Epidemiology

T. KREMASTINOU, M.D., Lecturer in Hygiene and Epidemiology G. PAPOUTSAKIS, M.D., Lecturer in Hygiene and Epidemiology
}

was slightly but not significantly $(P>0 \cdot 1)$ higher than that of the controls (mean age $27 \cdot 7$ years).

Blood samples were allowed to clot and the separated serum was stored at $-20^{\circ} \mathrm{C}$. Screening for $\mathrm{HBAg}$ was done by counterimmunoelectrophoresis (Pesendorfer et al., 1970) and immunodiffusion test (Prince, 1968); for $\mathrm{HBAb}$ by passive haemagglutination assay (Vyas and Shulman 1970); for syphilis by Wasserman as well as by R.P.R.* card test; and for SGPT by a modified method of Reitman-Frankel (1957). Differences between frequency rates were tested by $\chi^{2}$ test with Yates's correction.

\section{Results}

HBAg was present in $13(4.4 \%)$ of the prostitutes and in 13 $(3.4 \%)$ of the controls (table I, fig. 1). This difference was not statistically significant $(P>0 \cdot 1)$. In two of the $\mathrm{HBAg}$-positive prostitutes and one of the controls SGPT levels were above normal but not higher than 100 Karmen units. HBAg was more prevalent in prostitutes than in controls in almost all age groups. There was also a definite tendency for the $\mathrm{HBAg}$ prevalence to decrease with age in both prostitutes and controls. HBAg when found was still present in all cases on retesting at least six months later, but in no case was HBAb present.

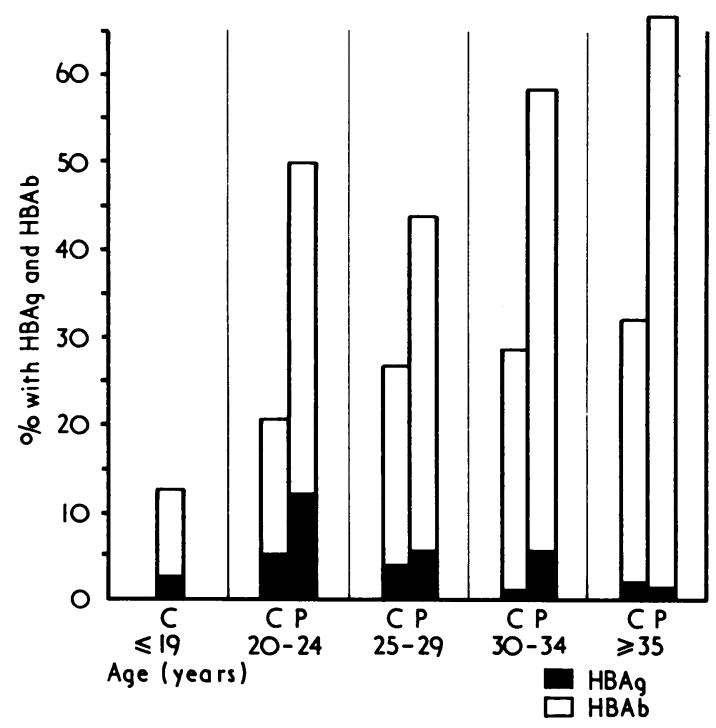

FIG. 1-Prevalence of bepatitis $B$ antigen (HBAg) and antibody (HBAb) among prostitutes $(P)$ and pregnant women (C) in relation to age.

*Hynson, Westcoff and Dunning, Inc., Baltimore, Maryland, U.S.A. 